\title{
INTERNATIONAL CONTROL OF INTERNATIONAL LITIGATION: WHO BENEFITS?
}

\author{
HANS SMIT*
}

I

\section{INTRODUCTION}

The enormous growth of international intercourse since the last World War has brought a corresponding increase in litigation with international aspects. International arbitration is rapidly becoming the preferred mode for settling international disputes. ${ }^{1} \quad$ However, domestic courts continue to provide important forums for settling international disputes. Unfortunately, adjudication by domestic courts of disputes with international aspects, frequently involving foreign parties, has created special problems.

\section{A. Adjudicatory Authority}

Persons normally prefer suit at home over being sued abroad. Asserting personal adjudicatory authority over someone away from home, therefore, raises problems, especially when this authority is based on circumstances other than those that affiliate the defendant with the forum. ${ }^{2}$ Foreign litigants are likely

\footnotetext{
Copyright $\odot 1994$ by Law and Contemporary Problems

* Fuld Professor of Law and Director, Parker School of Foreign and Comparative Law, Columbia University.

1. The caseload of the Court of International Arbitration of the International Chamber of
} Commerce in Paris is increasing from year to year. See 3 HANS SMIT \& VRATISLAV PECHOTA, WorLd ARBITRATION REPORTER 3072 (1987). Other institutions, such as the American Arbitration Association, the London Court of Arbitration, and the Stockholm Chamber of Commerce, have made deliberate efforts to capture part of this growing litigation business. See, e.g., Hans Smit, The Future of International Commercial Arbitration: A Single Transnational Institution?, 25 COLUM. J. TRANSNAT'L L. 9, 12-13 (1986); Hans Smit, The New AAA Rules for International Cases, 2 AM. REV. INT. ARB. 1, 1 (1991).

2. In the United States, the Supreme Court has consistently ruled that the Due Process Clause requires that the (foreign) defendant have minimal contacts with the forum that render the exercise of adjudicatory authority reasonable. See, e.g., Asahi Metal Industry Co. Ltd. v. Superior Court of California, Solano County, 480 U.S. 102 (1987); World-Wide Volkswagen Corp. v. Woodson, 444 U.S. 286 (1980); see also Helicopteros Nacionales de Colombia S.A. v. Hall, 466 U.S. 408 (1984) (holding that substantial contacts required for in personam jurisdiction if claim asserted does not arise from the contacts). These contacts may be attenuated in the case of related claims against multiple defendants. Mullane v. Central Hanover Bank \& Trust Co., 339 U.S. 306 (1950). The question of whether minimal contacts are required becomes particularly acute in cases of mass torts, in which the court cannot effectively dispose of all claims unless it has the requisite adjudicatory authority. In these cases, it appears reasonable, and therefore constitutional, to exercise adjudicatory authority over all claimants. See In re DES Cases, 789 F. Supp. 552, 569-88 (E.D.N.Y. 1992); see also Hans Smit, Common and Civil Law Rules In Personam Adjudicatory Authority: An Analysis of Underlying Policies, 21 INT.'L \& COMP. L.Q. 335 (1972) (arguing that the plaintiff's and forum's interests in providing an appropriate forum provide relevant considerations). 
to object to the exercise of adjudicatory authority on bases they regard as unreasonable. Thus far, their objections have not been addressed by international agreement except in the Common Market. ${ }^{3}$ In the United States, the Due Process Clause of the Constitution prohibits reliance on an unreasonable basis of adjudicatory authority. ${ }^{4}$ The unreasonableness and unconstitutionality of reliance on such a basis can be asserted both in a direct attack during the proceedings and in a collateral attack on a judgment founded on an improper basis. ${ }^{5}$ However, the Due Process Clause provides no protection against the rendition and enforcement abroad of a foreign judgment rendered against a U.S. citizen, nor does any international agreement to which the United States is a party provide such protection. On the contrary, the most important international agreement regulating the exercise of international adjudicatory authority, the European Convention on the Enforcement and Recognition of Judgments, which displaces domestic laws that might provide such protection, specifically mandates recognition of judgments based on excessive bases of adjudicatory authority against U.S. citizens, while precluding such recognition against residents of treaty adherents. ${ }^{6}$

The United States attempted to address this problem by negotiating a treaty with Great Britain to regulate the exercise of adjudicatory authority and the recognition of foreign judgments. The United States expected that, if this treaty could be negotiated successfully with Great Britain, it might provide the

It continues to be questioned whether the so-called transient basis of adjudicatory authority can survive due process inquiry. Presence is a traditional rule of in personam adjudicatory authority. Ordinarily, a person served where he or she is present will have substantial contacts with the state in which he or she is served. If he or she does not have such contacts and is served while he or she is merely a transient, the problem of transient jurisdiction arises. Many endorsed the view that transient adjudicatory authority could not survive the Supreme Court's consistent rulings requiring that the exercise of all forms of adjudicatory authority, whether personal or in rem, must meet the reasonableness test. See Robert C. Casad, Shaffer v. Heitner: An End to Ambivalence in Jurisdictional Theory?, 26 KAN. L. Rev. 61 (1977); Linda J. Silberman, Shaffer v. Heitner: The End of an Era, 53 N.Y.U. L. REv. 33 (1978); Irving Younger, Quasi in Rem Defaults after Shaffer v. Heitner: Some Unanswered Questions, 45 BROOKLYN L. REv. 675 (1979). The Supreme Court's decision in Burnham v. Superior Court of California, 495 U.S. 604, 619-622 (1990), has inclined some to the view that mere transient presence may survive a due process challenge. However, in Burnham, a father who visited his children in California was found to be subject to California's in personam power in an action for the children's support. His contacts with California were, therefore, more than his mere transient presence. Justice Scalia's opinion does appear to give undue weight to the father's mere presence in California, but judges in U.S. courts often say more than what is necessary to decide the precise issue before them. The question of whether mere transient presence is a constitutional basis for in personam adjudicatory authority is, therefore, still very much open.

3. The Common Market Convention on the Recognition and Enforcement of Judgments excludes judgments based on exorbitant bases such as the ones described supra in note 2 from recognition and enforcement, except that it requires such recognition and enforcement against nonresidents of countries that have adhered to the Convention. 2 CCH Common Mkt. Rep. I 6003 at 5045 (updated 1968). It changed the rules theretofore generally prevailing, which denied recognition to such judgments across the board. On these aspects, see Kurt H. Nadelmann, Jurisdictionally Improper Fora in Treaties on Recognition of Judgments: The Common Market Draft, 67 ColuM. L. REv. 995, 1000-02 (1967).

4. The transient jurisdiction basis may be the exception. See supra note 2.

5. Treinies v. Sunshine Mining Co., 308 U.S. 66, $69-70$ (1939), reh'g denied, 309 U.S. 693 (1940).

6. See supra note 3 . 
prototype for similar agreements with other European countries. ${ }^{7}$ However, no treaty was ever concluded. Although the United States and Great Britain both accord liberal recognition to foreign judgments, agreements on a number of details appeared impossible. ${ }^{8}$ The experience with these negotiations illustrates the difficulty of reaching agreement even between countries that have virtually identical rules on the subject. ${ }^{9}$ Since U.S. litigants could derive significant benefits from a properly drafted treaty, ${ }^{10}$ the United States is cooperating in efforts to draft such a treaty under the auspices of the Hague Conference.

\section{B. Service of Documents}

Another problem that arises in international litigation is service of litigation documents in a foreign country. Many foreign countries are inclined to regard such service as the performance of an official act that, if done without their consent, infringes upon their sovereignty. This attitude is regrettable. Service of litigation documents in a foreign country is designed merely to give notice of proceedings brought in another country. The proper governmental attitude should be to permit and facilitate such notification, unless the foreign proceedings themselves can properly be regarded as unfair or improper. For example, if a court proceeds on an improper jurisdictional basis or the proceedings themselves offend domestic notions of fairness, a government may properly resist service. However, when foreign nations object to local service of foreign litigation documents, they ordinarily do not do so because they do not wish to lend assistance to unfair or improper proceedings. Instead, they object on the conceptual ground that it infringes upon their sovereignty ${ }^{11}$ or, after the Hague Convention on service of judicial and quasi-judicial documents became effective,$^{12}$ on the ground that the service should be made pursuant to the Convention. ${ }^{13}$

Reliance on the latter ground lends support to the view that an international agreement may not be the best vehicle for dealing with problems of service.

7. On the draft that was developed, see Hans Smit, The Proposed United States-United Kingdom Convention on Recognition and Enforcement of Judgments: A Prototype for the Future?, 17 VA. J. INT'L L. 443 (1977). block.

8. The recognition and enforcement of judgments based on the antitrust laws created a stumbling

9. See Smit, supra note 7, at $459-63$.

10. For one thing, such a treaty could eliminate exorbitant bases of adjudicatory authority as proper bases for judgments entitled to recognition. See supra note 3. It would also secure recognition and enforcement for U.S. judgments abroad. At present, such treatment is hard to come by. See Friedrich K. Juenger, The Recognition of Money Judgments in Civil and Commercial Matters, 36 AM. J. COMP. L. 1, 3-4 (1988).

11. For the view that service by a private person on behalf of a foreign litigant does not infringe upon a state's sovereignty, see Hans Smit, International Co-Operation in Litigation: Some Observations On the Roles of International Law and Reciprocity, 9 NETH. INT'L L. REV. 137 (1962).

12. Convention on the Service Abroad of Judicial and Extrajudicial Documents in Civil or Commercial Matters, opened for signature Nov. 15, 1965, art. 2, 20 U.S.T. 361, 658 U.N.T.S. 163 [hereinafter Hague Service Convention].

13. See infra text accompanying notes 67-71. 
Indeed, as will be shown below, domestic reform may be far better for this purpose. $^{14}$

One may well question why foreign countries assume such formalistic stances. After all, service of a judicial document serves merely the function of giving notice. ${ }^{15}$ Why should a foreign state care how notice is given in connection with foreign proceedings? ${ }^{16}$ How is its sovereignty affected and why does it insist on litigants following treaty routes that invariably are more cumbersome, more expensive, and more time consuming?

The invocation of the concept of sovereignty sounds hollow. It is hard to see any substance in the notion that a state's sovereignty is threatened by transmittal of a notice that certain steps will be taken in a proceeding in a foreign country. ${ }^{17}$ Surely, such a view displays the most abstract and sterile notion of sovereignty imaginable. We live in an international world in which persons increasingly get involved in international litigation. States should foreswear invocation of notions of sovereignty in favor of an attitude of international cooperation. The proper attitude is to extend a helping hand to foreign courts and litigants who wish to perform the salutary function of informing litigants of the fact that their interests may be affected by proceedings in a foreign court. Reliance on the concept of sovereignty in this context impedes development of a more effective and harmonious world community. It is antithetical to what right-minded governments should wish to promote.

Similarly, it is difficult to discern why states should insist that service be made exclusively in accordance with international agreements to which they are a party. International agreements regulating service should be, and claim to be, designed to facilitate service. They should, therefore, not be forced upon courts or litigants who wish to employ a method of service they find more attractive.

14. It is rather surprising that some commentators continue to prefer international agreements. One might have thought that the actual experience under the Conventions would have cured them of their rather romantic notion that international agreements are the preferable mechanism for dealing with the problems that arise in this area. For writers favoring the treaty approach, see, e.g., Stephen B. Burbank, The Reluctant Partner: Making Procedural Law for International Civil Litigation, 57 LAw \& CONTEMP. PROBS. 103 (Summer 1994).

15. Service may create in personam adjudicatory authority only when it is made within the territory within which the court is sitting. See supra note 2 . When the service is made in a foreign country, its only function is to give notice. When the defendant is a foreign corporation, the service has only a notice-giving function, even when it is made within the court's territory.

16. A state's only legitimate concern is that the person to be notified on its territory be notified in the manner deemed appropriate by the foreign court from which the notice emanates. That concern is best served by permitting the service to be made in the manner prescribed by the applicable foreign law. A state may also be concerned that its nationals and residents be notified in a manner it regards as appropriate. However, that concern can adequately be vindicated by the state's refusal to recognize a judgment that it regards to be based on inadequate service. It would appear inappropriate for a state to vindicate that concern by seeking to impose its standards on a foreign court with respect to proceedings in that court. Of course, a state that applies the rule that service that actually reaches the addressee is good service regardless of the manner in which the service is made (see infra note 22), cannot reasonably be heard to argue that the service should be made in the manner it prefers in those cases in which the service reached the addressee. Significantly, Germany, which so insistently argued in Volkswagenwerk Aktiengesellschaft v. Schlunk, 486 U.S. 694 (1988), that the service could properly be made only in the manner prescribed by the Service Convention, follows that rule. See infra note 22.

17. See Smit, supra note 11. 
What interest can a treaty state reasonably have in insisting that the treaty route be traveled? ${ }^{18}$

It is significant that states prefer to bandy about hollow phrases of sovereignty and accuse the United States of breaching its obligations assumed by international agreements rather than focus on the real reasons why they get so exercised about the transmission of notices on their territory. Since foreign states have not been forthcoming in this regard, one might be inclined to speculate about their real motivations. ${ }^{19}$ For example, it might be thought that states have some concern about whether persons on their territory are given the kind of notice that will effectively inform the addressee. ${ }^{20}$ However, since the notice, and disregard thereof, will produce only consequences abroad, it would appear that the state's interest in this regard can at most be minimal. ${ }^{21}$ Surely, in regard to notices emanating from the United States, such a concern is totally unwarranted, since the addressee of the notice can invoke constitutional protections, not ordinarily granted by foreign laws, that ensure that the notice will measure up to the due process clauses of the U.S. and state constitutions. ${ }^{22}$

In my judgment, the real reason why foreign states invoke their sovereignty and the alleged exclusivity of international agreements is that the persons to whom the notices are addressed wish to create as many impediments as possible to their being served and call for the assistance of their national governments in these efforts. Any procedural incident, with its attendant expenditure of time and money, will serve that purpose. It is no coincidence that the cases that have reached the appellate courts frequently involve large international corporations of foreign origin such as Volkswagen, Aérospatiale, and St. Gobain. They have the influence to prompt their governments to take action. It will take but a moment of reflection to realize that the only benefit these addressees can derive from the success of their governments' efforts is to impede the progress of the lawsuit and to make the giving of notice more difficult. ${ }^{23}$ This may serve their litigation strategy, but not the end of justice. As is often the case, invocations of exalted, but opaque, concepts of sovereignty and romantic appeals to the United States to observe its international treaties hide mundane and practical

18. For an identification of a state's possible interests and the view that it cannot properly support insistence upon the treaty route, see supra note 16

19. It is, indeed, remarkable that states that object to service being made in the U.S. manner have failed to identify their real interests in the matter other than the alleged concern for their sovereignty and U.S. compliance with treaty obligations.

20. See supra note 16 .

21. As stated in note 16 , supra, a state can protect that interest by denying recognition to the foreign judgment on its territory.

22. In civil law countries, there are no constitutional guarantees specifically relating to service of process. In fact, the signification au parquet, the service upon the prosecuting attorney, the traditional civil law service upon a person in a foreign country, does not require delivery to the addressee; delivery to the prosecuting attorney completes the service. See, e.g., PETER E. Herzog, Civil ProcedURE IN FRANCE 170-231 (Hans Smit ed., 1967). Service of that kind is unconstitutional in the United States. Wuchter v. Pizzuti, 276 U.S. 13 (1928).

23. In the end, service can, of course, be made in some manner. However, service may take so much time, effort, and expense that the litigant's interest in pursuing his or her case may abate. This is the classic stratagem of the litigant who seeks to avoid a decision on the merits. 
efforts to throw every possible obstacle in the way of being involved in a U.S. lawsuit. For the same reason, foreign litigants and governments object to extending the waiver of service device to foreign addressees. ${ }^{24}$ Of course, one may agree that the experience of being involved in a U.S. lawsuit is not a pleasant one. And one may agree that the U.S. litigation process is in dire need of improvement, but this cannot justify the efforts of those who, for their own purposes, seek to complicate it further.

\section{Obtaining Evidence Abroad}

Obtaining evidence abroad may also create problems. ${ }^{25}$ The evidence sought may be of various kinds: foreign official records, information on foreign law, and other documentary or testimonial evidence.

1. Foreign Official Records. U.S. rules of evidence that originated in the English common law imposed rather stringent authentication requirements that required a chain of authentications by foreign and U.S. officials. ${ }^{26}$ In practice, it was frequently difficult to meet these requirements. ${ }^{27}$ Simplification of these requirements, therefore, appeared desirable. ${ }^{28}$

2. Information on Foreign Law. The traditional rule of the common law was that foreign law should be pleaded, and proven by the party relying on it, as if it were a fact. ${ }^{29}$ As a consequence, proving foreign law required meeting the rules of evidence, under which the texts of foreign statutes had to be properly authenticated, and foreign treatises were not admissible under the hearsay rule. Therefore, less cumbersome ways of establishing applicable foreign law appeared desirable. The new rules developed by the Project on International Procedure and the U.S. Commission on International Rules of Judicial Procedure ${ }^{30}$ provide these procedures. Their essence is to permit U.S. courts to establish foreign law by any means they deem appropriate. Formal pleading and evidence rules do not apply. ${ }^{31}$ No assistance by a foreign court is needed. ${ }^{32}$

24. The most recently adopted amendments to the Federal Rules of Civil Procedure include a provision for waiver of service. See FED. R. CIV. P. 4(d). Under this provision, a person to be served may be asked to waive service. In case of refusal, the cost of making the service, including a reasonable attorney fee, may be assessed against the refusing party. As originally proposed, this amendment also extended to foreign service. As might be expected, foreign countries have already protested. In its new version, improper refusal to waive foreign service carries no sanctions.

25. See Hans Smit, International Aspects of Federal Civil Procedure, 61 CoLUM. L. REV. 1031, 1059. 63 (1961).

26. Id. at $1070-71$.

27. Id.

28. Id. at 1071 .

29. See Arthur R. Miller, Federal Rule 44.1 and the "Fact" Approach to Determining Foreign Law: Death Knell for a Die-Hard Doctrine, $65 \mathrm{MICH}$. L. REV. 613, 617 (1967).

30. See infra text accompanying notes $45-46$.

31. See FED. R. CIV. P. 44.1.

32. Since all information on relevant foreign law may be submitted without regard to the rules of evidence, it is far simpler to obtain such information informally than by making an application for assistance to a foreign court or other official, which may well be neither equipped nor authorized to render this type of assistance. Furthermore, unless the foreign court could be asked to apply the law 
3. Other Documentary or Testimonial Evidence. In international disputes, other forms of evidence may often also have to be obtained abroad. If it is in testimonial form, witnesses may have to be heard abroad. This causes difficulties if the manner in which testimony is given and recorded by foreign courts does not meet U.S. requirements, ${ }^{33}$ or if the foreign state objects to obtaining evidence within its borders in aid of foreign litigation. ${ }^{34}$

Obtaining documentary evidence should pose fewer problems. The manner in which it is obtained does not normally affect its evidentiary value. ${ }^{35}$ However, here again, the foreign state may object to its being produced. ${ }^{36}$

What has been said above in regard to foreign objections to service applies in large measure also to foreign objections to the production of evidence in aid of U.S. litigation. Of course, a foreign state may object to the exercise of measures of compulsion on its territory other than under its authority. It understandably wants to control the exercise of its police power. But that is never a real problem. Even the least initiated know that compulsory measures cannot be performed on foreign soil without the concurrence of the foreign sovereign. Some foreign states, invoking concepts of sovereignty, exclusivity of international agreements, ${ }^{37}$ and, most unfortunately, blocking statutes ${ }^{38}$ object to the production of evidence in their territory in aid of foreign litigation without recourse to measures of compulsion. Here again, it is difficult to discern a good reason for such objections. How is a foreign state's sovereignty affected in any meaningful way by requests for evidence to be used in a foreign

to the facts (and thus resolve the issue), its abstract formulation on its law might not be particularly helpful.

33. See Smit, supra note 25 , at $1058-59$.

34. Most unfortunately, foreign states are increasingly adopting so-called blocking statutes, which prohibit the taking of evidence for use in a foreign court. The most comprehensive statute of this kind is the French statute, Law No. 68-678 of July 26, 1968, J.O. at 7267, D.S.L. at 248, as amended by Law No. $80-538$ of July 16,1980 , J.O. at 1799 . D.S.L. at 285 , which provides that, except as provided in international agreements, "no person may request, seek or discover or communicate, in writing, orally or in any other form, documents or information of an economic, commercial, industrial, financial, or technical nature likely to be used as proof in or in the context of foreign judicial or administrative proceedings." The United Kingdom has enacted a similar statute. Protection of Trading Interest Act, 1980, ch. 11 (U.K.), 17 Halsbury 4th 219 (1993). The title of the Act is quite remarkable for its open recognition that its purpose is really the protection of English traders who are involved in litigation in foreign countries. Similar acts have been adopted in Canada, New Zealand, and other countries. Enacting blocking statutes may be the current vogue. Of course, these statutes are quite ineffective when the U.S. court has in personam power over the person who is in possession of the evidence. It will simply order that person to bring the evidence or him or herself to the United States and produce it there or, if that is not possible, order that person to produce the evidence regardless of the foreign prohibition. See, e.g., United States v. Bank of Nova Scotia, 691 F.2d. 1384 (11th Cir. 1982), cert. denied, 462 U.S. 1119 (1983).

35. If the evidence has been obtained in an illegal search, it may be inadmissible. An interesting question would arise if the illegality of the search would not affect its admissibility under foreign law.

36. The mere fact that the production would violate foreign law should not affect the admissibility of the evidence.

37. See infra note 50.

38. See supra note 34. 
court? ${ }^{39}$ And why insist on a foreign litigant's traveling a convention route that not only invariably is more expensive and time consuming, but also frequently will produce no results, ${ }^{40}$ rather than permit recourse to far simpler procedures that leave the witness free to refuse cooperation and do not involve exposure to local sanctions? ${ }^{41}$ It is because the answers to these questions are so clear that the drafters of the relevant rules of U.S. procedure deliberately set out to create the most flexible procedures that seek to avoid, to the extent possible, sanctions imposed in the place where the evidence is gathered. ${ }^{42}$

Of course, foreign insistence on compliance with local procedures or international agreements produces far more serious consequences for the U.S. litigant who seeks evidence than for the litigant who wants to make service. The foreign procedure or the international agreement may simply make it impossible to obtain the evidence. Non-common law countries normally follow procedures for questioning witnesses that produce inadmissible evidence and generally do not provide for the production of documentary evidence at all. ${ }^{43}$ Indeed, it is no coincidence that the Hague Evidence Convention specifically permits a state to refuse to cooperate in document discovery. ${ }^{44}$ Insistence on the unavailability of normal evidence gathering procedures therefore creates a significant (although inappropriate) protection for the foreign litigant: testimonial evidence can be obtained only in a generally less useful form and documentary evidence cannot be obtained at all. This goes a long way toward explaining why persons from whom evidence is sought in foreign countries are ever more intent on getting their governments to invoke sovereignty and the exclusivity of international agreements in their efforts to obstruct, as much as possible, the evidence-gathering process.

39. The only possible concern a state might have is that it may not wish to cooperate even in a passive way in the production of evidence for use in a proceeding that it finds offensive. An obvious example would be a proceeding in which a person is pursued in law because of his or her beliefs or the expression of ideas. However, the typical case is that of an action resulting from a commercial activity in which that type of consideration is irrelevant. In any event, states have not based their objections on grounds of that kind.

40. In Société Nationale Industrielle Aérospatiale v. United States Dist. Court for the So. Dist. of Iowa, 482 U.S. 522, 545-46 (1987), the record presented to the Supreme Court was replete with examples.

41. If the witness is a party, the U.S. court has the authority to compel him or her to produce the evidence on penalty of contempt or loss of that party's claim or defense. FED. R. CIV. P. 37 . If the witness is not a party, the U.S. court can compel production of the evidence only if the witness is a U.S. citizen or resident. 28 U.S.C. $\$ 1782$ (1988). There is no long arm statute authorizing the exercise of adjudicatory authority over witnesses abroad. The time is ripe for enactment of such a statute on both the federal and state level.

42. The reforms developed in the early 1960s maintained and streamlined the letters rogatory procedure seeking production of evidence abroad by recourse to compulsion imposed by a foreign court. See infra text accompanying notes 83-85. However, it should be stressed that such compulsion is not likely to produce useful evidence. See infra text accompanying note 43.

43. See Smit, supra note 25 , at 1058 .

44. Convention on the Taking of Evidence Abroad in Civil or Commercial Matters, opened for signature Mar. 18, 1970, art. 2, 23 U.S.T. 2555, 847 U.N.T.S. 231 [hereinafter Hague Evidence Convention]. Unfortunately, many adherents to the Convention have acted upon this permission. 


\section{The Manner of Dealing with the Problems that Have Arisen: DOMESTIC REFORM OR INTERNATIONAL REGULATION?}

In the early 1960s, the U.S. Commission on International Rules of Judicial Procedure, a body created by Act of Congress, ${ }^{45}$ set about addressing these problems. Since Congress had provided no funds to support the Commission's work, the Commission entered into an arrangement with the Project on International Procedure of the Columbia University School of Law. The Project performed the necessary research and prepared proposals for reform for the Commission and its Advisory Committee. ${ }^{46}$

An important threshold question facing the Project and the Commission was how the needed reform was to be effectuated. Some thought that an appropriate treaty should be developed that could then be presented in negotiations with other states. ${ }^{47}$ However, the Project was strongly of the view that the best way of proceeding was through reform of domestic laws. This latter view prevailed. ${ }^{48}$

An argument that proved persuasive was that it should first be determined what reforms could be achieved by changes in domestic law before a proper effort could be made to negotiate changes by international agreement. After all, it might appear that significant improvements could be made by domestic reform that would not require the concurrence of treaty partners. ${ }^{49}$ In fact, it might prove possible to achieve reform by domestic changes that might not gain the concurrence of treaty partners. ${ }^{50}$

45. Pub. L. No. 85-906, 72 Stat. 1743 (1958).

46. On this cooperation, see Smit, supra note 25 , at 1031 . These proposals encompassed proposed revisions of the Federal Rules of Civil Procedure, the Federal Rules of Criminal Procedure, Titles 18 and 28 of the United States Code, and the Uniform Interstate and International Procedure Act. For the text of these proposals, as enacted, see HANS SMIT; INTERNATIONAL CO-OPERATION IN LITIGATION: EUROPE App. A-C (1965).

47. This was the view strongly urged by Harry Leroi Jones, the Director of the Commission. This may explain why, in the legislative history of the statute that created the Commission, significant stress was laid upon this approach. See Burbank, supra note 14, at 107-11.

48. Indeed, when the Project and the Commission had completed the reforms of domestic law they developed, the Commission ceased its activities. At no time was consideration given to drafting conventions in the areas addressed by the Project and the Commission.

49. For example, by providing that service could be made by any nonparty over eighteen years of age, the need to obtain the assistance of a foreign process server was avoided. FED. R. CIV. P. 4(i)(1). Similarly, the provision that testimony could be taken before any person designated by stipulation or court order rendered unnecessary the assistance of any person authorized to administer oaths under foreign law. Id. at $28(\mathrm{~b})$.

50. The experience with the Hague Service Convention, supra note 12, and the Hague Evidence Convention, supra note 44 , has proved the accuracy of this judgment. See, e.g., the Hague Service Convention, supra note 12, art. 8, para. 2, and art. 10, U.S.T. at 363. U.N.T.S. at 168-71 (giving states the right to object to quite innocuous forms of service) and art. 15, para. 2, and art. 16, U.S.T. at 256465 , U.N.T.S. at 235,244 (providing that states may object to various forms of taking evidence even if no compulsion is used). Fortunately, the makers of the Conventions did not realize that the reforms developed by the Project and the Commission permitted service to be made by, and testimony to be taken before, private persons and, therefore, did not incorporate in these Conventions provisions authorizing states to prohibit these forms of making service or obtaining evidence. This circumstance 
Another argument for effectuating domestic reform first was that it was better to put domestic law in optimum shape before seeking to negotiate a treaty or treaties. Not only would this obviate the need for obtaining international agreement on changes that could effectively be made by domestic reform, ${ }^{51}$ but it would also permit the United States to present the best possible model for emulation by foreign countries.

Furthermore, it appeared uncertain whether foreign countries could be persuaded to relinquish objections they might have to performance of procedural acts on their territory merely because the United States was ready to conclude an agreement on the subject. Indeed, the United States did not raise objections against the performance of such acts on its territory in aid of foreign litigation and did provide substantial assistance in the performance of such acts. It would, therefore, not be in the position of offering any significant quid pro quo for concessions to be made by foreign states.

Added to these were the arguments that negotiating treaties might encourage foreign states to incorporate into those treaties prohibitions of certain forms of procedural acts that, in the absence of a treaty, would not be incompatible with their domestic laws, ${ }^{52}$ and that a treaty, and particularly a multilateral treaty, was likely to provide more limited assistance than might otherwise be available. ${ }^{53}$

The Project and the Commission decided, therefore, to concentrate their efforts on developing proposals for domestic reform. In order to ensure that these proposals would facilitate the performance of procedural acts abroad, the Project studied the laws of the European countries in which such acts would most likely be performed. ${ }^{54}$

The Project's studies and proposals for reform resulted in the Commission submitting to the appropriate bodies a series of proposals to amend the Federal Rules of Civil Procedure, the Federal Rules of Criminal Procedure, and the United States Code, and to adopt a Uniform Interstate and International Procedure Act. ${ }^{55}$ All of the proposals for reform, developed by the Project and the Commission, were enacted by the appropriate legislative bodies. They

induced the author not to urge the Senate to withhold its approval of these Conventions. Of course, at the time the Conventions were ratified, no one involved in the work of the Project and Commission thought that there was any merit to the notion that the Conventions might be regarded as exclusive. That notion was antithetical to the very foundations upon which the Project's and Commission's reforms were built.

51. It was realized that it would in all circumstances be preferable to avoid, as much as possible. involvement by foreign authorities, which would necessarily require the expenditure of additional effort, time, and money.

52. See, e.g., supra note 41.

53. This has also proved to be the case. The provisions in the Conventions that authorize a state to prohibit certain forms of making service and taking evidence, discussed in note 50 supra, have been invoked by states that theretofore had raised no objections to such service or method of taking evidence. See the recitals following these Conventions in MARTINDALE-HuBbell LAw DIGEST IC-2-3, IC-16-17 (1993). 46.

54. Its studies of the European laws relating to these subjects were published in SMIT, supra note

55. See id. 
appear to have worked well in practice. The number of reported cases resolving disputes that have arisen under them is very small-a circumstance that testifies to their efficacy. ${ }^{56}$

\section{III}

\section{The Subsequent Hague Conventions}

When the Project and the Commission had completed their work, the State Department decided that it would be worthwhile to persuade foreign states, particularly European countries, to follow the U.S. example and liberalize their laws. This initiative was in line with the Project's and the Commission's approach. If, indeed, foreign countries had followed the United States's example and had enacted similar laws, international cooperation in litigation would have benefitted immensely. None of the problems that have subsequently arisen under the Hague Conventions would have occurred. ${ }^{57}$ In the very limited areas in which U.S. courts and litigants could not have performed procedural acts abroad without foreign assistance, such assistance could easily have been obtained. ${ }^{58}$ Particularly, the production of testimonial and documentary evidence by unwilling nonparties could have been compelled efficaciously. ${ }^{59}$

The State Department's initiative was channelled through the Hague Conference on Private International Law, and Philip W. Amram, former Chairman of the Advisory Committee of the U.S. Commission on International Rules of Judicial Procedure, became the U.S. delegate to the Conference promoting the Project's and Commission's reforms. It should be stressed that neither the Project nor the Commission ever approved seeking further improvement through the Hague Conference. ${ }^{60}$ It is not unlikely that, if they had ever been consulted, they would have counseled against this approach. ${ }^{61}$

56. The experience under the Conventions has been quite different. They have spawned a large number of cases, two of which reached the Supreme Court. See supra notes 16, 33.

57. On these problems, see infra text accompanying notes 72-82.

58. Under 28 U.S.C. $\$ \S 1696,1782$ (1988) and the corresponding provisions in the Uniform Interstate and International Procedure Act, $\$ \$ 2.04,3.02,13$ U.L.A. 386, 391-92 (1986), a U.S. court, upon a simple request, renders the appropriate assistance.

59. A single application directly to the foreign court would have sufficed.

60. As indicated, supra text accompanying notes 45-56, the Commission and the Project had decided not to go beyond their proposals for unilateral reform. It is fair to speculate that they would have been most disconcerted by the subsequent developments under the Hague Conventions.

61. It should be noted that the State Department, in advocating ratification of the Conventions, had an agenda that did not necessarily put the interests of U.S. courts and litigants first. There can be no doubt that the United States had, in the past, not been particularly forthcoming in cooperating in this form of international lawmaking, and that it was most desirable that it show greater willingness in seeking cooperative solutions. It is for that reason that the Project successfully urged the State Department to join the Hague Conference and the Rome Institute on the Unification of Private Law. Since then, the United States's performance in these areas has been exemplary. However, it does not appear appropriate that we sacrifice the interests of U.S. courts and litigants upon the altar of international cooperation. We should fully participate in the efforts to legislate cooperatively in the international arena, but when this cooperation does not produce appropriate results, we should hold firm and refuse to accept those results. It might be preferable if the development of these types of conventions were channeled through a joint committee of the State and Justice Departments. 
Especially when judged in the light of subsequent developments, this approach was ill-advised and contributed greatly to frustrating the reforms developed by the Project and the Commission. The subsequent developments were by no means unforeseeable. Foreign states were increasingly being urged by important enterprises engaged in international commerce to protect them against U.S. litigation. $^{62}$ Therefore, it was most likely that these states would seek, in international agreements, to embody the restrictions their enterprises sought. ${ }^{63}$

It may fairly be said that even the boldest expectations of these enterprises were greatly surpassed by what eventually happened. Analysis of what the Conventions actually achieved will demonstrate this.

IV

\section{The OfFICIAL Records CONVENTION}

The provisions regulating proof of foreign official records developed by the Project and the Commission greatly simplified the authentication process: sufficient authentication consists of a foreign attestation backed by a U.S. certificate of genuineness of the signature and the official position of the foreign attestor. Thus, the uninterrupted chain of certificates required by prior law was abolished. However, the new provisions could not, and did not, abolish the requirement of a foreign attestation. ${ }^{64}$ To that extent, reliance on foreign cooperation remained necessary.

The Convention on the Proof of Foreign Official Documents, the first in this area to be prepared by the Hague Conference, ${ }^{65}$ does make a useful contribution to the simplification of authentication procedures. By providing for a single authentication issued by a central authority in each country, ${ }^{66}$ it carries forward the spirit of the domestic reforms effectuated in the United States and further simplifies the authentication process.

\section{The Service Convention}

The reforms introduced by the Project and the Commission relating to service sought to cope, to the extent possible, with the objections foreign states might have to the service of litigation documents on their territory. They provide for service to be made by any nonparty person over eighteen years of age, thus depriving of its force the argument that the making of service is an official act. ${ }^{67}$ They also authorize service to be made by registered mail, return

62. The emergence of the blocking statutes, see supra note 34 , provides a telling illustration.

63. See supra text accompanying notes $25-42$.

64. On these improvements, see Hans Smit, International Aspects of Federal Civil Procedure, 61 Colum. L. REV. 1031 (1961).

65. Judicial Procedure: Abolishing Requirement of Legalization of Foreign Public Document, Oct. 5, 1961, 33 U.S.T. 883, 527 U.N.T.S. 189.

66. Convention on Foreign Official Documents art. 6, U.S.T. at 886, U.N.T.S. at 194-95.

67. FED. R. CIV. P. 4(i)(1). For the view that service by a private person is not an official act against which the state on the territory of which the service is made can object on the ground of 
receipt requested. ${ }^{68}$ The fax machine had not yet been invented. If it had. been on the scene, service by fax, with the record of the transmission attached, would, most likely, have been made possible. ${ }^{69}$ Service can also be made by any person and method authorized by foreign law, pursuant to court order, or by letters rogatory, ${ }^{70}$ but these methods are unlikely to be used when service by. any adult nonparty or by registered mail is available. ${ }^{71}$

Under these rules, it is unlikely that a U.S. litigant will be unable to complete service in a foreign country. An objection by a foreign country is unlikely when service can be made without any official's intervention. ${ }^{72}$ In any event, such an objection is unlikely to be effective. ${ }^{73}$ It is only in the relatively rare case in which a foreign statute specifically prohibits the service to be made that a U.S litigant may face a problem. ${ }^{74}$ This problem, however, will not be that service which violates foreign law is invalid and ineffective. In drafting its new rules on foreign service, the Project and Commission deliberately refrained from requiring that the foreign service not violate foreign law. Rather, they intended that a possible violation of foreign law be irrelevant to the determination of whether the service was valid for U.S. purposes. They wished to preclude the argument that foreign law could affect the validity of the service. Arguments about compatibility with foreign law would introduce what might be difficult questions, the resolution of which would entail time, effort, and expense, ${ }^{75}$ that did not bear on the essential function of service, which is to give notice. Furthermore, whether the service was to be regarded as proper should be determined by U.S. rather than foreign law, the content of which might well be contrary to U.S. notions of propriety and fairness. ${ }^{76}$ Indeed, the

sovereignty, see Smit, supra note 11. As already noted, the Service Convention does not give a state authority to prohibit service by a private person. See infra text accompanying notes 88-94. A state may, by statute, prohibit the working of service by a private person. Article 271 of the Swiss Penal Code does so. See SMIT, supra note 46, at 361.

68. FED. R. CIV. P. 4(i)(1)(D); UNIF. INTERstate AND INTERNATIONAL PROCEDURE ACT $\S 2.01(\mathrm{a})(3), 13$ U.L.A. 382 (1986).

69. Service by fax should generally be made available. The fax machine provides a record of the transmission that furnishes adequate proof of service. Foreign states would have a difficult time objecting to service by fax. The attractiveness of this method of giving notice is that it requires no physical action by a person in the foreign state. In that regard, it is even better than mail transmission. The Federal Rules makers would do well to consider adding this method of making service. It appears considerably simpler and more efficacious that the newly introduced device of waiver of service.

70. Fed. R. Civ. P. 4(i)(1); Unif. InTERState and InTERnational Procedure ACT $\S 2.01(\mathrm{a})(2)(4)$ and (5), 13 U.L.A. 382 (1986).

71. A court order requires court intervention, as do letters rogatory, and both take time, effort, and money. Service in the foreign manner may create questions as to the applicable foreign law that may be exploited by the addressee who wishes to create problems.

72. For one thing, the foreign government will normally not know when the service is made.

73. Unless the foreign state has a penal statute forbidding the service, there is little the foreign state can do except protest. See also Smit, supra note 11.

74. The Service Convention may be such a measure. See supra note 66 . Article 271 of the Swiss Penal Code provides another instance.

75. Anyone who has been involved in proving foreign law in a U.S. court is familiar with the attendant problems and expense. Proving foreign law relating to the permissibility of service may prove particularly difficult when the foreign law is not statutory, but some amalgam of governmental policy, internal regulations, or both, as in Germany. Smit, supra note 46, at 190-200.

76. See, e.g., the signification au parquet discussed in id. at 124 . 
Project seriously considered introducing an affirmative provision to the effect that service was to be regarded as valid and effective as soon as the papers served actually reached the addressee, regardless of what method of communication was employed. It did not do so, however, because this would have introduced a reform that should cover all forms of service and would, therefore, have reached beyond the Project's mandate. ${ }^{77}$

The recently adopted amendment to the Federal Rules which precludes foreign service that violates foreign law $^{78}$ is, therefore, to be regretted. ${ }^{79}$ Indeed, this amendment, as well as that introducing a provision for waiver of service fortified by sanctions for failure to waive, appears to disregard that the purpose of service is to give notice. If the notice has been given, the goal of service has been accomplished, regardless of whether some foreign law that U.S. litigants are likely to find objectionable ${ }^{80}$ has been violated. Instead of asking a person to waive service, he or she can as effectively be served, and the rule should be introduced that the service is valid and complete as soon as a person has received the documents to be served. This rule, adopted by prominent foreign systems, ${ }^{81}$ would eliminate the large majority of useless contests about the validity of service. Under it, any party who sought to attack the service would establish the effectiveness of the service by acknowledging that it reached him. And a collateral attack would become a risky enterprise; for if it could be proved that the service, although in some way defective, actually reached the addressee in time properly to respond to it, it would be ruled valid and the judgment based on it unassailable. This would effectively eliminate all attacks on service made for the purpose of causing delay and expense. ${ }^{82}$

77. The Project similarly rejected a proposal that an overall due process limitation be put in new Rule 4(i) on the ground that the Due Process Clause operated as a limitation without needing statutory affirmation.

78. FED. R. CIV. P. 4(f).

79. It would have served a useful purpose if those who drafted original FED. R. CIV. P. 4(i) had been consulted on this proposal.

80. Article 271 of the Swiss Penal Code provides an excellent example. See supra note 67

81. Ironically, both Germany and Austria, which have objected to service on their territory without their consent as infringing upon their sovereignty, have these rules. See Smit, supra note 46, at 18, 179 (Zivilprozessordnung [ZPO] $\S 108$ (Aus.) and ZPO $\S 179$ (F.R.G.)).

82. It is no coincidence that the same foreign countries that object to service on their territory without their consent and strongly argue that the Service Convention is exclusive also object to extending the proposed waiver of service rule to foreign service. Extension of the waiver of service device to foreign service will significantly up the ante for foreign addressees who insist upon formal service. It may fairly be predicted that, if the waiver of service rule remains extended to foreign service, foreign addressees and their governments will argue that the request for waiver of service is the functional equivalent of actual service and is, therefore, also subject to foreign prohibitions and to exclusive transmission under the provisions of the Service Convention.

Adoption of the rule advocated in the text would be considerably more effective in coping with these problems. Unjustified noncompliance with a request for waiver does not dispense with the need to make the service. Under the rule here advocated, any informal transmission of the documents to be served that reaches the addressee constitutes effective service. For example, transmission by fax would suffice. An addressee who appeared would have no cause to complain. An addressee who did not appear would run the risk that the service would be ruled effective and the judgment based on it unassailable. This is a significantly bigger risk than merely having to pay for the cost of service. 
As can readily be seen, the rules on foreign service proposed by the Commission and the Project effectively avoid virtually all obstacles a foreign state might wish to create. Of course, if a foreign state, by statute, prohibits the making of foreign service on its territory, ${ }^{83}$ the server would have to cope with that statute. But even that might not preclude the service altogether. It would be difficult, if not impossible, for a foreign state to prosecute its own postal employee who delivered a foreign litigation document. Also, the person who served the process might be beyond the reach of the foreign state before it became aware of the service. ${ }^{84}$

As a consequence, any international agreement regulating foreign service of documents can be of only very limited utility to a U.S. court or litigant. There are only two things of value it could effectively do for a U.S. litigant. First, it could streamline the procedure for processing letters rogatory requesting service; but this would be a negligible benefit, because U.S. litigants normally want to avoid the delay, expense, and uncertainty attendant upon such a form of service. Second, it could eliminate foreign objections to service; this would also be of little interest to a U.S. litigant, for the objection would likely be eliminated only for a form of service that would not be attractive to a U.S. litigant, such as service through letters rogatory, and would continue in effect for other forms.

The Hague Convention on the service of judicial and quasi-judicial documents ${ }^{85}$ confirms the accuracy of this assessment. It does not provide for any form of service that is not already available to a U.S. litigant under the rules developed by the Project and the Commission. While it streamlines the procedure for processing letters rogatory, recourse to such letters is avoided by any U.S. litigant who appreciates the rich array of options domestic law offers.

Moreover, the Service Convention, apart from offering negligible benefits, creates some significant disadvantages. First, by specifically outlawing, or only conditionally permitting, some forms of service, it creates a treaty basis for foreign objections to such service. ${ }^{86}$ This is an important disadvantage, for the United States cannot as easily shrug off as irrelevant an asserted violation of a treaty it has ratified. Even this disadvantage would become insignificant, however, if the rule were adopted that defects in the service are cured by the actual receipt by the addressee of the documents served. ${ }^{87}$

A second overriding disadvantage of the Convention is that it has been construed by the Supreme Court to exclude, at least in part, ${ }^{88}$ recourse to methods of service that might otherwise be available under domestic law. ${ }^{89}$

83. Art. 271 of the Swiss Penal Code does so. See supra note 67.

84. This would certainly be the case if the service were made by fax transmission.

85. See supra note 12 .

86. See supra note 75.

87. See supra note 82.

88. In Volkswagenwerk Aktiengesellschaft v. Schlunk, 486 U.S. 694, 699-701 (1988), the Supreme Court ruled the Convention exclusive insofar as service outside the United States is concerned.

89. The Convention does not provide for service by an adult nonparty. In addition, the Convention permits a contracting state to preclude service by mail, service by diplomatic or consular agents upon nonnationals, and service by officials or other competent persons of the state of destination. Hague 
This construction, warranted neither by the history ${ }^{90}$ nor by the text ${ }^{91}$ of the Convention, goes far to nullify the substantial improvements brought by the rules developed by the Project and the Commission. It excludes recourse to the easiest, fastest, and least expensive forms of service, which are service by any adult nonparty, ${ }^{92}$ service by a person commissioned by the court, ${ }^{93}$ and, when a state objects, service by registered mail, return receipt requested, and service by a foreign process server. ${ }^{94}$ Furthermore, the Supreme Court's ruling is likely to promote, rather than reduce, useless litigation about whether service was properly made. Its ruling that service made in the United States on a foreign addressee does not come within the reach of the Convention will encourage service to be made in the United States on an alleged agent when it could more properly be made abroad. ${ }^{95}$ It is also likely to engender protests by treaty partners who deem this construction to be faulty and not warranted by the Convention. ${ }^{96}$

Perhaps U.S. courts and litigants could live with the Service Convention if it were not construed as exclusive. In that event, it would not affect personal service by an adult nonparty and service by registered mail, return receipt requested ${ }^{97}$-the most preferable forms of service from a U.S. point of view. This construction would also appear to accord with the expectations of the principal U.S. delegate at the Hague Conference, who had no intention of sacrificing so readily the substantial gains achieved by the Advisory Committee (of which he was the Chairman) and who urged ratification on the ground that it would only help U.S. litigants. ${ }^{98}$ It would preclude service specifically forbidden by the Convention, but this would not be a matter of great moment, since other, nonforbidden, methods of service would be readily available. ${ }^{99}$

Service Convention, supra note 12 , arts. 8(2), 10, 20 U.S.T. at 363, 658 U.N.T.S. at 168-71.

90. As the U.S. delegate to the Hague Conference, Philip W. Amram, testified before the Senate, the Convention was to provide only alternative methods of service. See Burbank, supra note 14, at 12931. It would have made no sense for the United States to expend many years of efforts on improving its own laws merely to jettison most of the improvements by adhering to a Convention that would preclude their use.

91. The Convention, in Article 1, provides only that it "shall apply in all cases ... where there is occasion to transmit a judicial or extrajudicial document for service abroad." Hague Service Convention, supra note 12 , art. 1, 20 U.S.T. at 362,658 U.N.T.S. at 164,165 . The quoted words by no means provide that the Convention shall apply exclusively in such cases. The quoted words, sensibly construed, mean no more than that the Convention shall apply, and its methods of service shall be available, when a judicial or quasi-judicial document is to be served abroad.

92. FED. R. CIV. P. 4(i)(1).

93. Id.

94. Hague Service Convention, supra note 12, art. 10(c), 20 U.S.T. at 363,658 U.N.T.S. at $170,171$.

95. Foreign corporations are likely to go out of their way to provide that persons acting on their behalf have no authority to accept service. The circumstances of the individual case will decide whether such persons can properly be regarded as agents under the law. The question will ultimately have to be decided by the courts.

96. As a consequence, the United States's adherence to the Convention has produced exactly the contrary of what the State Department hoped to achieve.

97. At least, as long as the foreign state did not object. Hague Service Convention, supra note 12, art. 10 (a), 20 U.S.T. at 363,658 U.N.T.S. at $168,169$.

98. See the testimony of Philip W. Amram referred to by Burbank, supra note 14, at 129 n.217.

99. See supra note 89. 
However, if the construction given to the Service Convention by the Supreme Court is to be maintained, ${ }^{100}$ it would appear advisable for the United States to terminate its adherence to it. ${ }^{101}$ Such termination would again make available to U.S. courts and litigants most of the manners of service created by the new rules developed by the Project and the Commission. It would also put an end to continuing protests by treaty partners that the Supreme Court, by not extending the exclusive effect of the Convention to service on foreign addressees or their agents in the United States, has put the United States in the position of violating the Convention.

\section{VI \\ THE EVIDENCE CONVENTION}

Letters rogatory are the traditional means for obtaining testimonial and documentary evidence abroad. They are formal requests issued from a domestic court to a foreign court through diplomatic channels. Developed in European practice, they are disfavored in the United States for a number of reasons. They require substantial litigation efforts, including making applications to two courts, settling their proper terms, and attending to their proper execution. They normally involve substantial expense: authenticated translation must be prepared, transmission fees must be paid, and foreign lawyers may have to be retained to present them to the foreign court or to see to their proper execution. Typically, the results they produce are not worth the efforts expended in processing them. Foreign courts are wont to record the testimony taken in the forms of summaries dictated by the judge to the clerk which, even if admissible in the United States ${ }^{102}$ are not particularly useful. Letters rogatory seeking the production of documentary evidence are frequently returned unexecuted on the ground that the foreign court lacks the authority to compel its production. ${ }^{103}$

Taking into account the limitations of letters rogatory as a proof-taking device, the Project and the Commission concentrated their efforts on trying to improve other proof-taking methods. The new rules they developed render these methods more flexible and are designed to avoid possible foreign objections. Depositions may be taken on notice before any person authorized to administer oaths under either U.S. or foreign law or pursuant to stipulation. ${ }^{104}$ Furthermore, any person designated by stipulation will have the authority to administer an oath in the deposition taken before him or her. ${ }^{105}$

100. It is not particularly likely that the Supreme Court will reverse itself.

101. This would require action by the President.

102. FED. R. CIV. P. 28(b), as amended pursuant to the Project's and the Commission's proposals, urges U.S. courts not to reject these summaries too readily. However, their prohibitive force is likely to remain limited.

103. See, e.g., Société Nationale Industrielle Aérospatiale v. United States Dist. Court for the So. Dist. of Iowa, 482 U.S. 522 (1987) (containing examples of such conduct).

104. FED. R. CIV. P. 28(b).

105. FED. R. CIV. P. 29. 
This greatly reduces the possibility that a foreign state can effectively object to the taking of such a deposition within its territory. In addition, the service of a subpoena, whether ad testificandum or duces tecum, was greatly liberalized by both extending its reach ${ }^{106}$ and by providing for recourse to the new, more flexible rules for their service in a foreign country. ${ }^{107}$ Since U.S. courts have the power to compel compliance with discovery rules over all persons who are parties, the new rules permit U.S. litigants to obtain testimonial and documentary evidence in an effective way, without recourse to cumbersome and expensive judicial and diplomatic procedures, in almost all cases. The only exception is that the new rules do not, and cannot, compel the production of evidence by an unwilling person who is neither a party nor a U.S. national or resident. This can be compelled only by a foreign court that has the requisite power under foreign law. Of course, the new rules do not grant dispensation from the application of any applicable blocking statute. Unfortunately, an increasing number of nations, in one form or another, prohibit the production of evidence to be used in foreign litigation. ${ }^{108}$ When these prohibitions apply, obtaining evidence under the new rules may involve their disregard. In practice, this has not been an overwhelming problem. When the U.S. court has adjudicatory authority over the person from whom the evidence is sought, it can direct him or her to produce it at some place where the prohibition does not apply or, if necessary, direct the production of the evidence in disregard of the prohibition. ${ }^{109}$ However, when that is not possible, recourse to the compulsory powers of a foreign court may afford the only means of securing the evidence. It is questionable whether this is a significant drawback. Obtaining evidence from an uncooperative witness may not be a particularly useful enterprise in any event. In many cases, a lawyer may prefer to have the court draw adverse inferences from the uncooperative person's refusal to produce the evidence rather than rely on what ultimately can be obtained from a hostile witness through recourse to foreign processes that may not produce particularly helpful information. ${ }^{110}$ However, if that evidence must be obtained and can be obtained only by the exercise of foreign compulsion, recourse must be had to a foreign court.

Of course, while an international agreement may be necessary to overcome a foreign prohibition, it may not be necessary to obtain foreign compulsion.

106. On this reform, see Hans Smit, International Litigation Under the United States Code, 65 Colum. L. Rev. 1015, 1035-40 (1965).

107. New sections 1782 and 1783 (of 28 U.S.C.) provide for service in the manner prescribed by FED.

R. CIV. P. 4(i)(1).

108. See supra note 34 .

109. See supra note 34 .

110. As already indicated, compulsory production of documentary evidence is generally not available in civil law countries. Compelled testimony, when available, will normally be in the form of a summary dictated by the court. See supra text accompanying notes 33-36. 
Many foreign courts provide this assistance without an international agreement, as do U.S. courts. ${ }^{111}$

Whether it is worthwhile to have recourse to an international agreement, and specifically to the Evidence Convention, depends on whether the rather limited benefits it can offer a U.S. court or litigant outweigh its disadvantages. If the Evidence Convention is construed as not being exclusive, it is arguably worthwhile since it streamlines the processing of letters rogatory, makes available compulsion in some cases in which it might not otherwise be available, and may avoid foreign prohibitions. The Supreme Court has ruled this Convention nonexclusive; U.S. adherence to it may, therefore, appear justified. However, the Supreme Court's ruling is not dispositive of the problems the Convention may cause. First, the Supreme Court intimated in its opinion that a U.S. court may, in the interest of comity, opt for a Convention procedure rather than one provided by domestic law. ${ }^{112}$ This is undesirable. Many U.S. courts have little experience in matters of this kind and may well prefer to try the Convention route first even if recourse to a route provided by domestic law would be far easier and less expensive. The proper approach would leave the choice to the litigant, who is in the best position to evaluate the procedure that is most likely to produce results. Additionally, foreign countries may regard the Supreme Court's decision as misconstruing the Convention and therefore erroneous. Although this view is baseless, since neither the text nor the purpose of the Convention justifies it being regarded as exclusive,${ }^{113}$ they are unlikely to accept the Supreme Court's having the last word in the matter. The Convention thus creates the kind of friction between states that it should be designed to avoid.

If the Convention were construed as being exclusive, it would be little short of disastrous, for it would, in many cases, preclude the very kind of evidencetaking that is most useful in U.S. litigation. Depositions on notice before persons authorized to administer oaths by foreign or U.S. law or pursuant to stipulation, procedures not regulated by the Convention, would be precluded. In addition, adherents to the Convention would be permitted to preclude document discovery ${ }^{114}$ and discovery of nationals of the discovering state that entails what the Convention regards as compulsion. ${ }^{115}$ Indeed, if the Convention were regarded as exclusive, it could become an instrument for frustrating, rather than facilitating, discovery.

111. 28 U.S.C. $\S 1782$ (1988) (enacted as part of the reforms developed by the Project and the Commission); see Smit, supra note 106, at 1015.

112. Société Nationale Industrielle Aérospatiale v. United States Dist. Court for the So. Dist. of Iowa, 482 U.S. 522, 540-46 (1987).

113. See supra notes $91-92$.

114. Hague Evidence Convention, supra note 44 , art. 23, 23 U.S.T. at 2568,847 U.N.T.S. at 237, 245.

115. Id. art. 15, 23 U.S.T. at 2564,847 U.N.T.S. at $235,244$. 


\section{VII}

\section{CONCLUSION}

\section{A. The Case for Denouncing the Service and Evidence Conventions}

As matters now stand, it would appear desirable for the United States to denounce the Service Convention. Since the Supreme Court has ruled it exclusive when the service is to be made abroad, it makes service abroad a more cumbersome, time consuming, and expensive act, though in the end it will probably be possible for service to be made even under the Convention. Another disadvantage of continued adherence to the Service Convention is the encouragement of service on someone in the United States, with the attendant litigation over whether that person could be served as an "agent."116

The case with respect to the Evidence Convention is more difficult. Since the Supreme Court properly ruled it nonexclusive, the liberal foreign discovery provisions of the Federal Rules remain available. Nevertheless, continued adherence to the Convention may cause problems. Less sophisticated courts, heeding what the Supreme Court said in Aérospatiale ${ }^{117}$ may be inclined to try the Convention method first. This may cause the expenditure of significant time and money, especially if the Convention method does not work, which it frequently will not if documentary evidence is sought. In addition, the United States's continued adherence to the view that the Convention is not exclusive may provoke further irritation and frustration on the part of other treaty adherents that have a different view.

All in all, it would appear that, in the case of both Conventions, the disadvantages of continued adherence substantially outweigh the advantages.

B. The Lack of Benefit of the Service and Evidence Conventions to Other Adhering States in Their Relations to the United States

It should be stressed that the view that the Service and Evidence Conventions do not serve the purposes for which they were designed and impede, rather than improve, international cooperation in litigation, is not in any way influenced by a desire to circumvent legitimate concerns of foreign states to control the performance of procedural acts within their territories. Foreign states should have considerable freedom in regulating the procedure in their

116. It has been argued that foreign states may refuse to recognize a U.S. judgment that is based on service not pursuant to the Convention. There are a number of responses to this contention. First, most countries do not recognize U.S. judgments even if they are based on service pursuant to the Convention. Second, there is no good reason for a foreign country not to recognize a U.S. judgment merely on the ground that service was not made pursuant to the Convention. See supra note 16. Its only reason for doing this is to compel a U.S. litigant to use the more cumbersome Convention method. In any event, it is for the U.S. litigant to decide whether the possibility of nonrecognition of the judgment is a sufficient reason for foregoing the more convenient U.S. method of service. As indicated, in most cases that will not be a disadvantage of moment.

117. Aérospatiale, 482 U.S. at 540-46. 
courts. However, they should also permit other states to control the procedure in their courts. All states should cooperate to promote these freedoms.

Limiting the freedom of other states to control their own procedure to the extent it requires the performance of procedural acts in a foreign country can properly be defended only if the state asked to permit or facilitate this performance has a legitimate interest of its own in the limitations it seeks to impose. The mere circumstance that the procedural acts to be performed are unknown to domestic procedure does not suffice for this purpose, nor does reliance on outdated concepts of territorial sovereignty.

The United States has acted affirmatively on these notions. It provides in broad terms for liberal assistance to foreign courts and litigants who wish to make service, or obtain evidence, in the United States. ${ }^{118}$ As a consequence, if the United States were to terminate its adherence to the Service and Evidence Conventions, no detriment would be suffered by other adherents to these Conventions. They will continue to enjoy the very same assistance for which the Conventions now provide. Indeed, to the extent the Conventions are nonexclusive, U.S. courts may, in many instances, render more liberal assistance than foreign litigants can obtain from their own courts. ${ }^{119}$ In a real sense, therefore, the United States practices what it preaches. Regrettably, the Service and Evidence Conventions do not. 
